\title{
SAND-DUNE VEGETATION OF IGNEADA COAST IN THE THRACIAN PART OF TURKEY
}

\author{
Ali KAVGACI*
}

\begin{abstract}
Igneada is located in the northwest part of Turkey on the Black Sea coast and it is also near the national border between Turkey and Bulgaria. The Igneada region was accepted as one of the most important plant areas of Turkey. In this work, a study was made on the phytosociological structure of Igneada sand dune vegetation, which is the one of the important components of the richness in the region. At the end of the assessment of the data, 3 communities were defined. These communities are Otantho-Leymetum sabulosi, Medicago rigidulaCionura erecta basal community and meadow behind the sand dune. The part of the sand dune closest to the sea has width of $30 \mathrm{~m}$, ascends with a specific inclination and has no vegetation coverage. Behind this part, Otantho-Leymetum sabulosi occurs at places where the sand dune has an unstable structure. The Medicago rigidula-Cionura erecta basal community appears behind Otantho-Leymetum sabulosi and the sand dune has a stable structure at these areas. Behind these communities, another vegetation belt occurs, formed by the species that are cosmopolite or characteristic for meadow vegetation.
\end{abstract}

Key words: Igneada, nature conservation, phytosociology, sand dune.

\section{Izvleček}

Igneada se nahaja v severozahodnem delu Turčije na obali Črnega morja ob državni meji med Turčijo in Bolgarijo. Glede rastlinske raznovrstnosti je območje Igneada eno najpomembnejših v Turčiji. V članku je obravnavana fitocenološka struktura vegetacije peščenih sipin, ki je ena najpomembnejših sestavin rastlinskega bogatstva območja. Prikazane so tri rastlinske združbe: Otantho-Leymetum sabulosi, temeljna združba Medicago rigidula-Cionura erecta in travnik, ki se pojavlja za peščeno sipino. Del peščene sipine, ki je najbližje morju in je širok 30 metrov, se hitro dviga in je brez vegetacije. Za njim se na nestabilnem delu sipine nahajajajo sestoji asociacije Otantho-Leymetum sabulosi. Sledijo sestoji temeljne združbe Medicago rigidula-Cionura erecta na stabilnem delu peščene sipine. Sledi pas vegetacije, ki ga sestavljajo kozmopolitske vrste ali vrste, značilne za travniško vegetacijo.

Ključne besede: Igneada, varstvo narave, fitocenologija, peščene sipine.

\section{INTRODUCTION}

Natural resources have been negatively affected by industrialization, irregular urbanization and population increase. As a result of these effects, the conservation of natural resources, biological diversity and their sustainable use are the main problems of the world today. While ecologists and botanists emphasize the importance of biologi- cal diversity, politicians are also aware of the sensitivity of these processes. In this sense, scientists have paid special attention to these affairs and increasingly carried out many studies on biological and ecological diversity during the last decades (Magurran 1988, 2004). Botanists and ecologists especially have devoted more attention to special ecosystem types due to their sensibility.

\footnotetext{
*Southwest Anatolia Forestry Research Institute, PK 264, 07002 Antalya-Turkiye, alikavgaci1977@yahoo.com
} 
Dune ecosystems are one of these sensitive ecosystems. Although there is no extended study covering all coasts in Turkey, some local phytosociologic studies have been conducted (Uslu 1974, Uslu 1977, Géhu \& Uslu 1989, Uslu \& Géhu 1990; Kilinç \& Özen 1990; Karaer et al. 1997, Kilinç \& Özdemir 1998; Terzioğlu 1998). The plant communities on the coasts of Thrace except Igneada coast were studied by Géhu \& Uslu (1989)

Igneada province, which includes many different ecosystems, such as floodplain (longoze) forests, high forests with Quercus frainetto, Q. petraea, Q. cerris, Carpinus orientalis and Fraxinus ornus, lakes, swamps, shrub communities, sand dune and sea, is very important, according to the ecosystem diversity. As a result of this richness, the Igneada region is accepted as one of the most important plant areas of Turkey (Özhatay et al. 2003). In this work, studies were made on the phytosicological structure of Igneada sand dune vegetation, which is the one of the important components of the richness in the region.

\section{MATERIAL AND METHOD}

Igneada is located in the northwest part of Turkey on the Black Sea coast, and it is also near the national border between Turkey and Bulgaria (Fig. 1). Igneada has tall sand dune vegetation, which is about $7-8 \mathrm{~km}$ long. The physiognomy of the sand dune is mainly formed by Ammophila arenaria, Leymus racemosus, Medicago marina and Cionura erecta. There is also a shrub community behind the sand dune vegetation, at the transition zone between sand dune, forests and swamps. Paliurus spinachristi, Phillyrea latifolia and Ligustrum vulgare are the main scrub species in this community.

There is no meteorological station in Igneada. Because of this, the climate of the research area was examined using the data of Kumköy Meteorology Station in Istanbul (Anon. 2006). The yearly average rainfall is about $800 \mathrm{~mm}$ and the average temperature is $13{ }^{\circ} \mathrm{C}$. The hottest month is August and the coldest month is February. According to the Thornthwaite (1948) climate system, the research area has a humid and mesothermal sea climate.

The Flora of Turkey and The East Aegean Islands (Davis 1965-1985, Davis et al. 1988, Güner et al. 2000), The Flora Europea (Tutin et al. 19641980), Flora Orientalis (Boissier 1967-1988), and other sources (Bonnier 1986, Baytop 1998, Seçmen \& Leblebici 1997) were used to identify the specimens. Experts were consulted in some controversial cases.

The field research studies were performed in May 2005. In the selected areas, relevé sites were selected subjectively to represent the maximum diversity of sand dune. Plots of $100 \mathrm{~m}^{2}$ were usually located in places that are homogenous to make relevés. In each plot, a list of all vascular plants was made and each species was assigned a cover value according to the nine degrees of the Braun-Blanquet Scale (Braun-Blanquet 1964, Westhoff \& van der Maarel 1973).

The relevés were stored into the TURBOVEG database program (Hennekens \& Schaminèe 2001). The classification of the data was carried out with cluster analysis in the program PC-ORD 4 (McCune \& Mefford 1999). The relative Euclidean distance as a similarity measure and the beta-flexible algorithm with $\beta$ : -0.25 for dendrogram construction were used. The clusters of the communities were selected subjectively from the resulting dendrogram so that they had a clear ecological interpretation.

One of the clusters was not classified at association level, according to the Braun-Blanquet system, because of its floristic and structural properties. This cluster was only identified at alliance level. For further classification, the system of Kopecký \& Hejný (1974), which is regarded as a developed form of the Braun-Blanquet system and makes possible classification at lower level (Kopecký 1992, Kopecký et al. 1995), was used for this cluster.

The relationships between the communities and Ecological Indicator Values (Pignatti 2005) were visualized with the ordination in the CANOCO 4.5 package (ter Braak \& Šmilauer 2002), using the Canonical Correspondence Analysis (CCA).

Diagnostic species of the accepted clusters were determined in the JUICE 6.3 program (Tichý 2002) on the presence/absence basis by calculating the fidelity of each species to each cluster, using the phi coefficient of the association (Chytrý et al. 2002). While determining the diagnostic species, the threshold degree of fidelity was subjectively selected as 0.50 . The results of the classification were given in a vegetation table.

The distribution of the species to the phytogeographic regions (Yaltirik \& Efe 1989) and their growth forms, according to the Raunkiaer (1934) were also mentioned. 


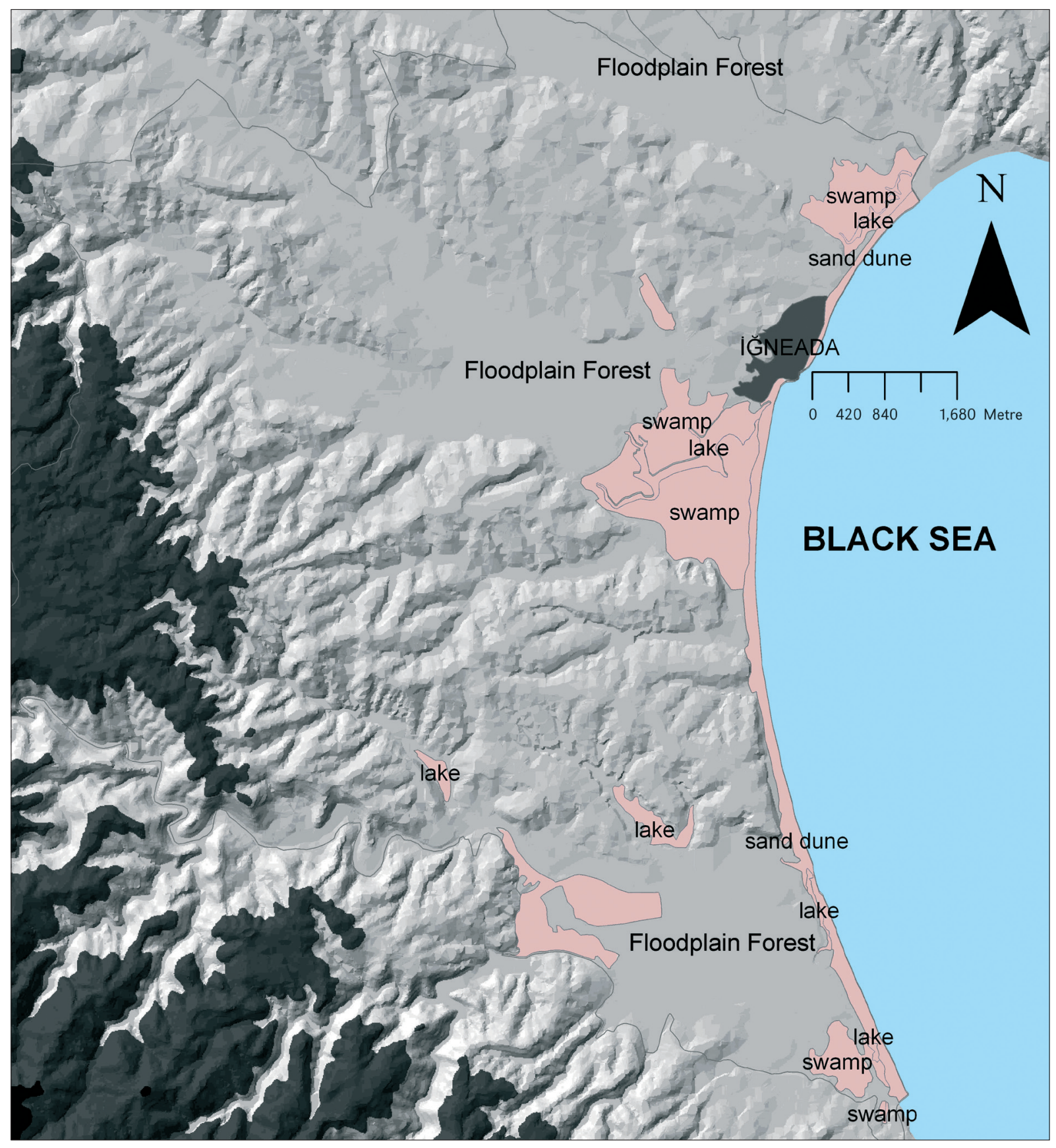

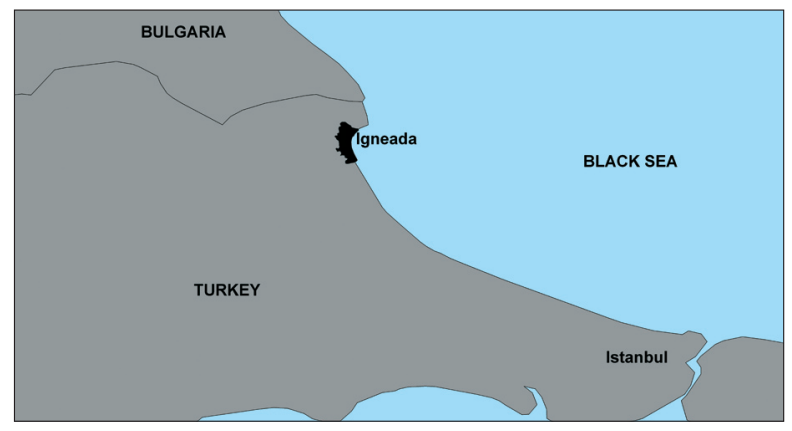

Figure 1: Geographical position of Igneada in Turkey.

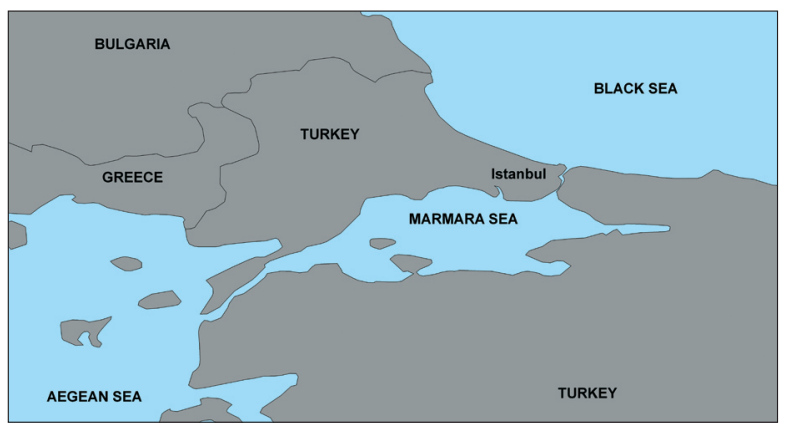

Slika 1: Geografski položaj območja Igneada v Turčiji. 


\section{RESULTS}

First of all we made a cluster analysis of relevés. At the end of the assessment of the data, 3 clusters were accepted (Fig. 2), that are mostly ecologically interpretable and represent three vegetation types presented in Table 1.

Based on the results of the numerical analyses, the following syntaxonomical scheme of the material was proposed:

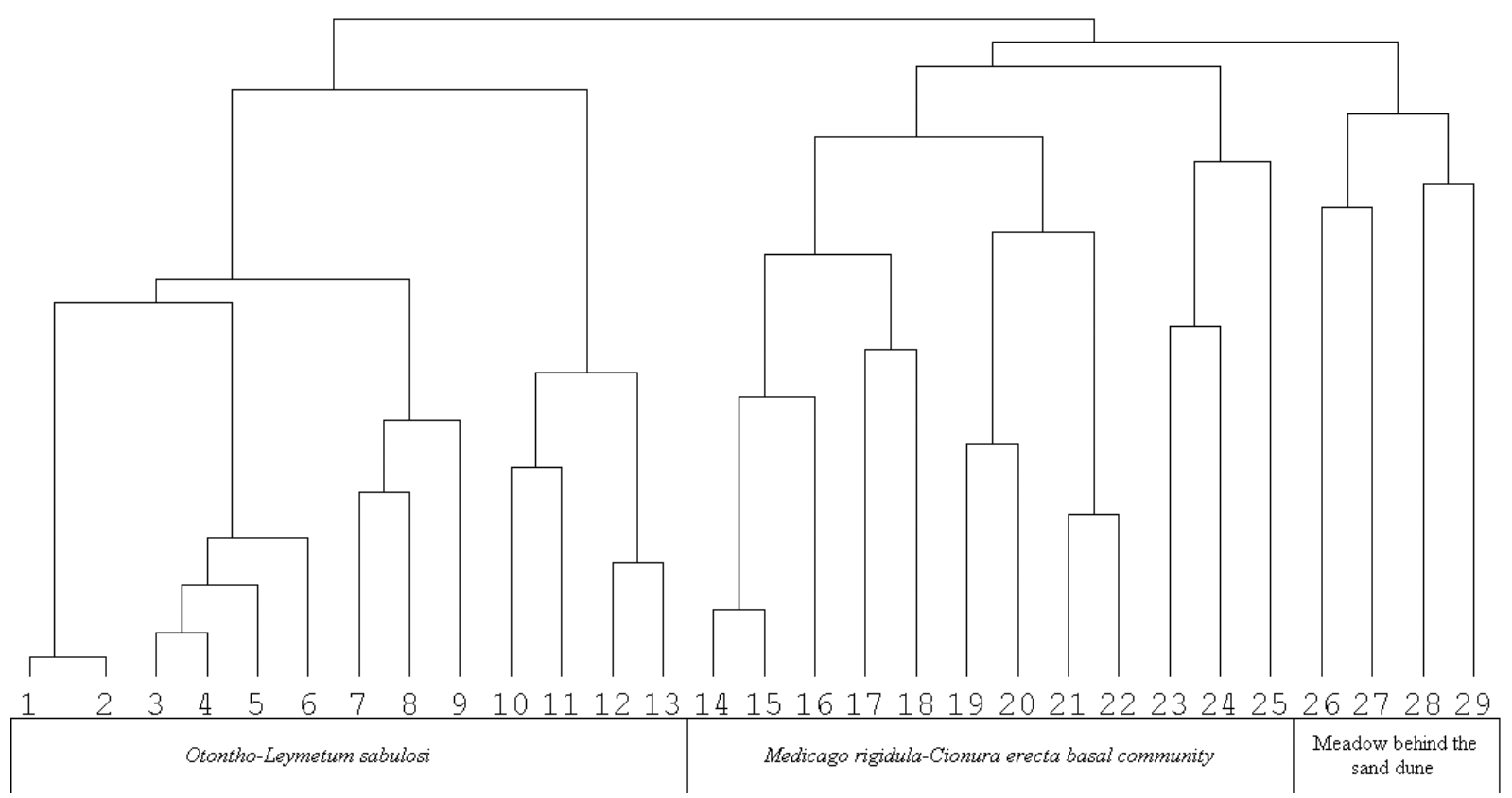

Figure 2: Dendrogram obtained by the cluster analysis of relevés.

Slika 2: Dendrogram klastrske analize popisov.

AMMOPHILETEA Br.-Bl. et Tx-ex Westhoff et al. 1946

AMMOPHILETALIA Br.-Bl. 1933

AMMOPHILION ARUNDINACEAE Br.-Bl. 1921

Otantho-Leymetum sabulosi Géhu \& Uslu 1989

TUBERARIETEA GUTTATAE Br.-Bl. 1952 em. Rivas-Martinez 1978

MALCOLMIETALIA Rivas-Goday 1957

MARESION NANAE Géhu et Alii 1986

Medicago rigidula-Cionura erecta basal community

Meadow behind the sand dune

Depending on the site conditions, the floristic composition of sand dune changes from sea to the inland area. This difference of floristic composition indicates the occurrence of different plant communities. The lakes, swamps, forests and especially the topography of forests behind the sand dune affect the vegetation structure of the sand dune ecosystem. These three communities cover the different parts of the sand dune, depending on the distance to the sea, and the occurrence of these communities on different parts of the sand dune is completely related with their ecological properties.

The ordination shows the relationships between sand dune communities and Ecological Indicator Values (Pignatti 2005) (Fig. 3). It is possible to conclude from this ordination that

Otantho-Leymetum sabulosi, which is the closest community to the sea (Fig. 4), contains the species indicating the highest soil reaction, temperature and light at a local level. On the other hand, Medigaco rigidula - Cionura erecta basal community, which appears behind the Otantho - Leymetum sabulosi has a more continental character. Meadow behind the sand dune is formed by the species that indicate higher nutrition and soil moisture than those forming other communities. It can be concluded from these results that although the soil reaction lowers down to the neutral level along the way from sea to inland, the soil moisture and nutrition increase. 


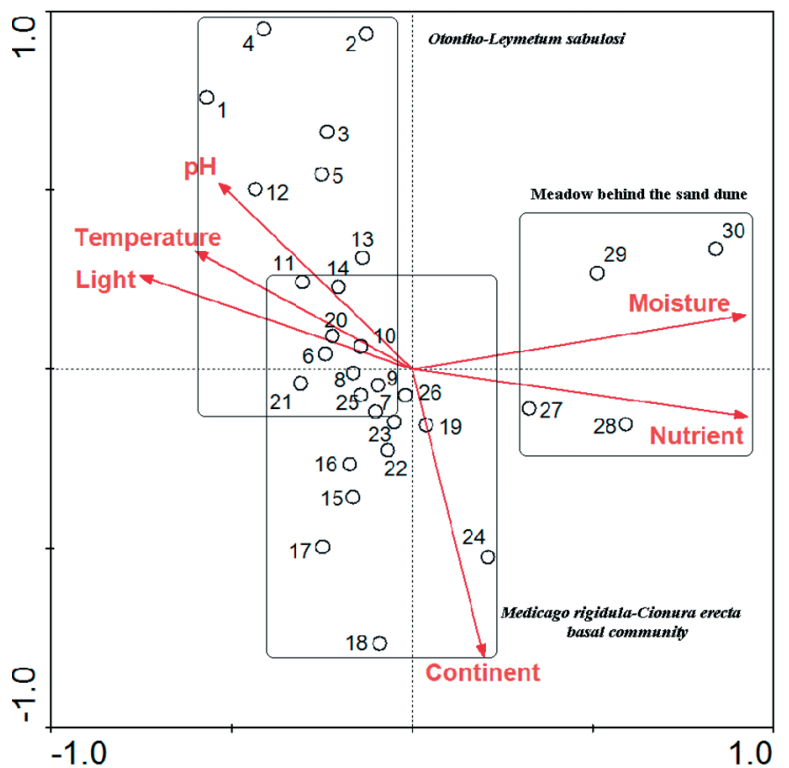

Figure 3: Ordination of relation between communities and Ecological Indicator Values (the number corresponds to the sequence number of the relevés in Table 1).

Slika 3: Ordinacijski diagram vegetacijskih popisov in ekoloških indikacijskih vrednosti (številke se nanašajo na oznake popisov v Tabeli 1).

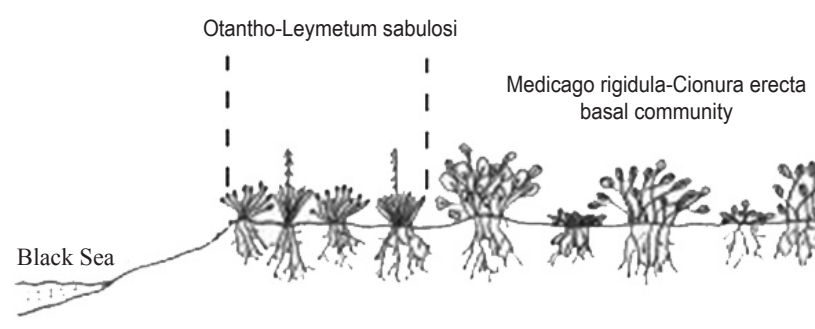

Figure 4: Zonation of vegetation on Igneada sand dune from sea to the hinterland.

Slika 4: Conacija vegetacije na peščenih sipinah Igneade od morja proti notranjosti.

\section{Otantho - Leymetum sabulosi}

The first approximately $30 \mathrm{~m}$ of the sand dune is under the heavy effect of sea waves and is vegetation free. Behind this zone, the topography becomes flatter and Otantho - Leymetum sabulosi appears. The total abundance of the species is often low. In addition to the heavy effects of human usage for tourism, overgrazing is another negative affect on this community. Ammophilla arenaria, Eryngium maritimum, Leymus racemosus subsp. sabulosus, Stachys annua, Otanthus maritimus are the character species of this community. Centaurea kilaea, Silene sangaria, which are endemics, Cionura erecta, Maresia nana, Silene dichotoma, Hypochaeris radicata, Secale sylvestre and Lolium rigidum with high abundance accompany these character species. In this area, the topography is less rough and locally has small hillocks and also has unstable conditions.

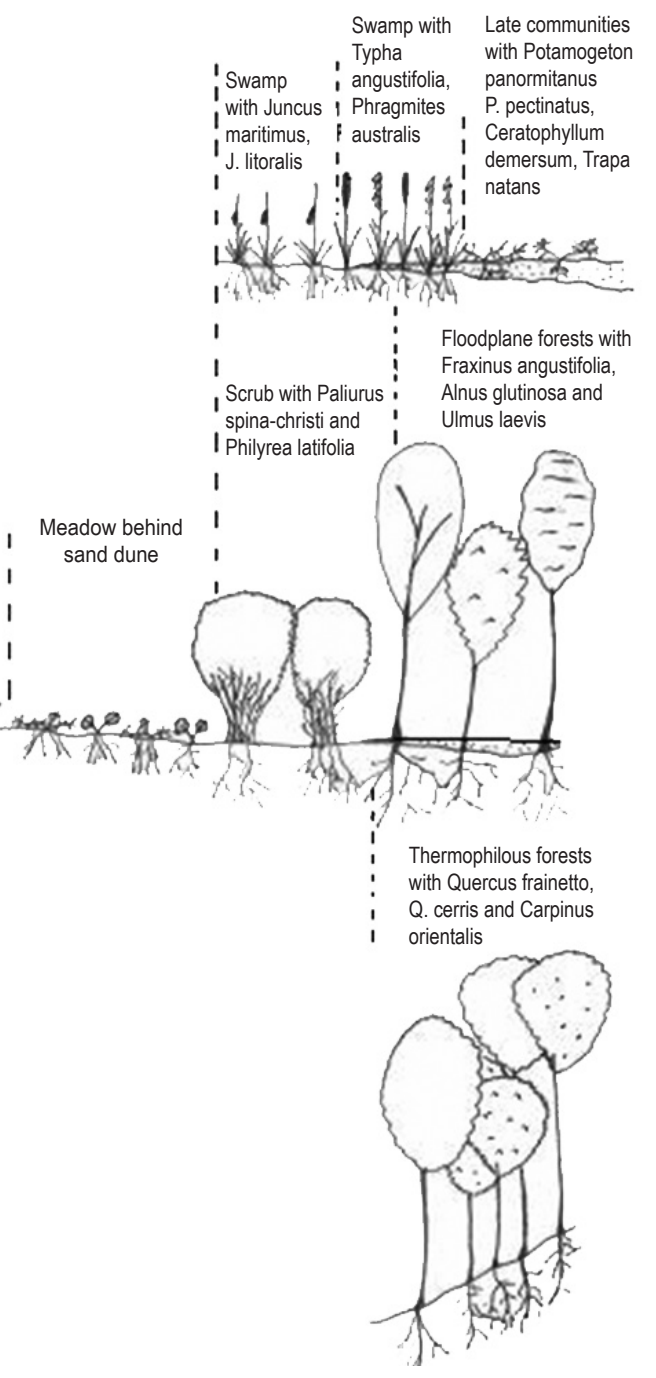




\section{Medicago rigidula - Cionura erecta Basal Community}

Along the way from sea to the hinterland, Medicago rigidula - Cionura erecta basal community under the alliance Maresion nanae appears behind the Otantho - Leymetum sabulosi. The entire group of relevés of this community is clearly separated from the OtanthoLeymetum sabulosi. The distinguishing species of this community are: Cionura erecta, Cerastium pumilum, Medicago rigidula, Muscari neglectum, Teucrium polium. This community locally characterizes a more stable sand dune structure. It seems that the sand motion stops at these areas. The topography at these areas is nearly flat and has some small hillocks and hollows.

\section{MEADOW BEHIND SAND DUNE}

On the inner part of the sand dune, the floristic composition is more different than the ones closest to sea. Vegetation at this part of the sand dune is formed by species characterizing meadow vegetation more than sand dune. Actually, this part of the sand dune could be a destruction of the littoral with a complex mixture of species. It is possible to find the indicators of trampled soils of fresh habitats such as Cynodon dactylon and Rumex pulcher with high abundance at these areas. On the other hand, the characteristic species of fine soils such as Parentucellia latifolia and Oenanthe fistulosa occur. Because of this structure of the area, it was not classified as a community, but merely identified as meadow behind sand dune. The over-grazing is the main reason for this floristic complex structure.

The sand dune has a stable structure at these areas. The floristic difference between this community and the others is due to its ecologic structure. The soil is fresher than the other communities at this part of the sand dune. Cynodon dactylon, Eryngium campestre, Vulpia ciliata, Trifolium campestre, Poa bulbosa, Petrorhagia velutina, Parentucellia latifolia, Leontodon tuberosus and Arenaria serpyllifolia are the dominant species at this part of the sand dune. Due to the favorable site conditions, the floristic composition includes a considerable number of species.

\section{DISCUSSION}

Sand dune ecosystems generally consist of three different segments (Oberdorfer 1952). There is no vegetation coverage on the part of sand dune nearest to the sea. This part is regularly washed by waves. The area behind this part is morphologically unstable and covered by high graminoids. The last and farthest section from the sea has a stable sand dune structure and is formed by dwarf shrubby species. Tzonev et al. (2005) mentioned that the sand dune ecosystems of the Black Sea could entirely be divided into two main groups. The first one of these is unstable sand dunes and the second one is formed by the sand dunes which have a fixed dune behind a shifting one.

The sand dune ecosystem structure of Igneada conforms to the explanation of Oberdorfer (1952). There is a stable sand dune behind the unstable one. The closest part of the sand dune to the sea has a width $30 \mathrm{~m}$, ascends with a specific inclination and has no vegetation coverage. Behind this part, Otantho-Leymetum sabulosi occurs at places where the sand dune has an unstable structure. The Medicago rigidula - Cionura erecta basal community appears behind Otantho-Leymetum sabulosi and the sand dune has a stable structure at these areas. Cionura erecta, which is a dwarf shrub, shapes the physiognomy of the vegetation. Behind these communities, another vegetation belt occurs, formed by the species that are cosmopolite or characteristic for meadow vegetation.

Wind is the most effective factor in the forming of sand dunes (Tzonev et al. 2005). Because the wind does not come across any barrier until reaching the sand dune, it importantly affects the sand dune structure and its vegetation. There is a reverse relationship between the motion of a sand dune shaped by the wind and the structure of vegetation. If the vegetation is denser, the sand dune motion is slower. The dense structure of Igneada sand dune vegetation and the presence of forests behind the sand dune decrease the negative effects of wind on sand dune motion.

In terms of floristic composition, Igneada sand dune vegetation has significant similarities with Greek (Sykora et al. 2003) and Bulgarian (Tzonev et al. 2005) sand dune vegetation, but the plant communities of Igneada sand dune vegetation do not appear in these countries. Otantho-Leymetum sabulosi characterizing the unstable sand dunes has a large distribution along the Black Sea coastal region of Thrace (Géhu \& Uslu 1989).

Most of the species included in the sand dune composition in Igneada are psammophytic. The classification of the species belonging to the Mediterranean phytogeographic region is evident (Fig. 5). Beside this it is also notable that the spe- 
Otontho - Leymetum sabulosi

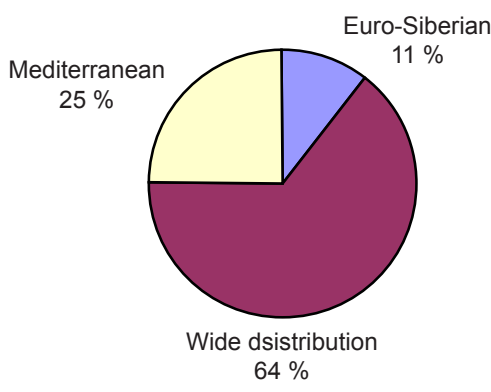

Meadow behind sand dune

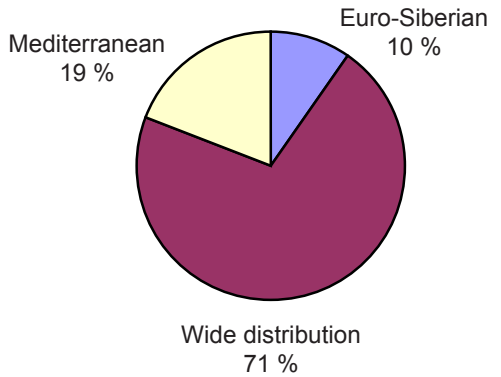

Medicago rigidula - Cionura erecta basal community

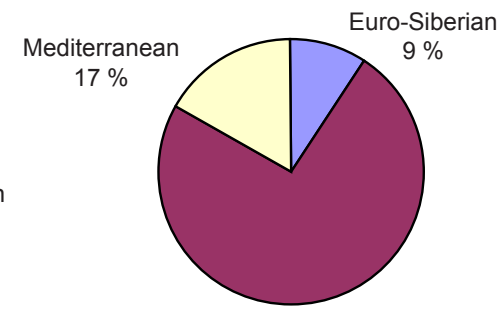

Wide dsistribution $74 \%$

Figure 5: Distribution of the species on the sand dune according to the phytogeographic region.

Slika 5: Distribucija vrst na peščenih sipinah glede na fitogeografsko pripadnost.

cies, which are either multi-area elements or have not yet been accepted as members of any phytogeographic area reach to a high proportional degree on sand dune vegetation. Mediterranean phytogeographical regions are represented by a higher proportion than the Euro-Siberian phytogeographic region in the sand dune plant communities.

Hemicryptophytes and therophytes are dominant life forms in the sand dune vegetation (Fig. 6).

Otontho - Leymetum sabulosi

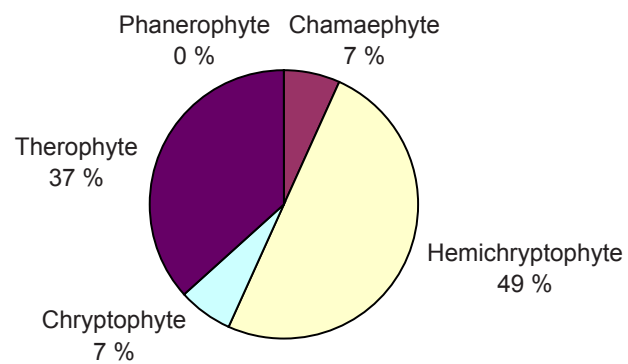

Meadow behind sand dune
So the sand dune vegetation has a therophytohemicryptophytic physiognomy. While the proportion of hemicrptophytes decreases $(49 \%, 44 \%$, $38 \%$ ) along the way from sea to the hinterland, the proportion of therophytes increases $(37 \%, 44 \%$, $52 \%)$. It could be concluded that this difference is a result of the sand dune motion. The stable sand dune structure on the inland part makes the site conditions more available for therophytes.

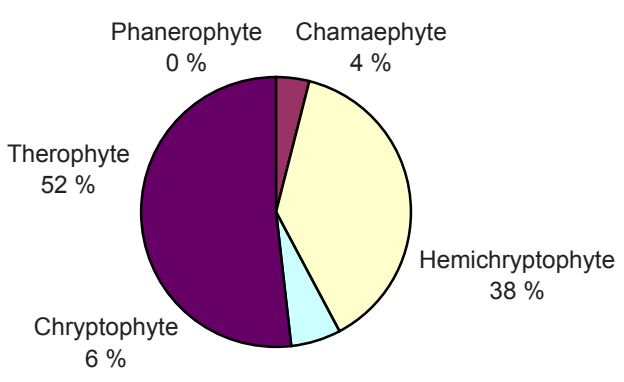

Figure 6: Growth form distribution of species according to the Raunkiaer's growth form Slika 6: Distribucija življenskih oblik po Raunkaier-ju. 
Centaurea kilaea, Silene sangaria, which are endemics and Pancratium maritimum, which is a vulnerable species according to the Turkish Red Data Book (Ekim et al. 2000) intensively take place in the composition of Otantho-Leymetum sabulosi and Medicago rigidula - Cionura erecta basal community. In addition to that, when the floristic composition is compared with the other coasts of the Marmara Sea (Géhu \& Uslu 1989) the richness of the Igneada sand dune can easily be seen. On the other hand, this richness rests on very sensitive conditions, because of the anthropogenic affects on it, such as human usage for tourism and overgrazing. Igneada sand dune vegetation, as in the other coastal parts of the Black Sea (Lovrić \& Rac 1991), has a specific and rich biological structure.

In terms of biologic and ecologic diversity, the Igneada region is very rich (Kavgaci 2007). While making a management plan of the region, the sensitivity of it must be taken into consideration and tourism activities and grazing must be carried out without any destruction to ecosystems and especially to sand dunes.

\section{ACKNOWLEDGEMENTS}

This study was funded by the Scientific and Technical Research Council of Turkey (project TOGTAG3313). I would like to thank Dr. Andraž Čarni and the workers of the Biology Institute of the Slovenian Research Center for their kind help during assessment of the data. I thank Prof. Dr. Jean Marie Géhu and Prof Dr. Gulen Ozalp for their welcome suggestions. I also thank Dr. Mehmet Calikoglu and Dr. Fahrettin Tilki for correction of the English text.

\section{REFERENCES}

Anon. 2006: The data of Kumkoy Meteorological Station. Istanbul.

Baytop, A. 1998: İngilizce - Türkçe Botanik Klavuzu. İ. Ü. Eczacilik Fakültesi Yayini, No 4058/70, 375 pp.

Boissier, E. 1867-1888: Flora orientalis, Vol. 1-5, Supplement by Buser, R. Geneve.

Bonnier, G. 1986: Flore Complète Illustrée en Coleurs de France, Suisse et Belgique. Vol. 1-7, Paris.

Braun-Blanquet, J.1964:Pflanzensoziologie. Grundzüge der Vegetationskunde. Springer Verlag, Wien-New York, 865 pp.
Chytrý, M., Tichý, L., Kolt, J. \& Botta- Dukát, Z. 2002: Determination of diagnostic species with statistical fidelity measures. Journal of Vegetation Science 13: 79-90.

Davis, P. M., Milli, R. R., \& Tan, K. 1988: Flora of Turkey and the East Aegean Islands. Vol. 10, Edinburgh University Press, Edinburgh.

Davis, P. M. 1965 - 1985: Flora of Turkey and the East Aegean Islands. Vol. 1-9, Edinburgh University Press, Edinburgh.

Ekim, T., Koyuncu, M., Vural, M., Duman, H., Aytaç, Z. \& Adigüzel, N. 2000: Türkiye Bitkileri Kirmizi Kitabi (Eğrelti ve Tohumlu Bitkiler). Türkiye Tabiati Koruma Derneği yayini, 246 pp.

Géhu, J-M. \& Uslu, T. 1989: Données sur la végetation littorale de la Turquie du Nord - Ouest. Phytocoenologia 17(4): 449-505.

Güner, A., Özhatay, N., Ekim, T. \& Başer, K. H. C. 2000: Flora of Turkey and the East Aegean Islands. Vol. 11, Edinburgh University Press, Edinburgh.

Hennekens, S. M. \& Schaminée, J. H. J. 2001: TURBOVEG, a comprehensive data base management system for vegetation data. Journal of Vegetation Science 12: 589-591.

Karaer, F., Kutbay, H.G. \& Kilinç, M. 1997: The flora and vegetation of the coastal dunes of the East Black Sea region. Turkish Journal of Botany 21: $177-185$.

Kavgaci, A. 2007: Demirköy- İğneada longoz ormanlari ve çevresinin bitki toplumlari ve kuruluş özellikleri. PhD thesis, İÜ. Fen Bilimleri Enstitüsü, Istanbul, 215 pp.

Kilinç, M. \& Özen, F. 1990: Orta Karadeniz Bölgesi kiyi kumullari vejetasyonunun Asasyasyon Analizi Metodu ile siniflandirilmasi, X. Ulusal Biyoloji Kongresi Botanik Bildirileri 2: 291-297.

Kilinç, M. \& Özdemir, C. 1998: Sarikum (Sinop) kumul vejetasyonunun numerik metotlarla siniflandirilmasi, XIV. Ulusal Biyoloji Kongresi Bildiri Kitabi 1: 362-382.

Kopecký, K \& Hejný, S. 1974: A new approach to the classification of anthropogenic plant communities. Vegetatio 29: 17-20

Kopecký, K. 1992: Syntaxonomische Klassifizierung von Pflanzengesellschaften unter Anwendung der deduktiven Methode. Tuexenia 12: 13-24.

Kopecký, K., Dostalek, J. \& Frantik, T. 1995: The use of the deductive method of syntaxnomic classification in the system of vegetational units of the Braun-Blanquet approach. Vegetatio 117: $95-112$. 
Lovrić, A. \& Rac, M. 1991: A comparison of the coastal vegetation of Greece, Yugoslavia, Bulgaria and Turkey. Botanika Chronika 100: 315-324.

Magurran, A. E. 1988: Ecological diversity and its measurement. Princeton University Press, Princeton, $179 \mathrm{pp}$.

Magurran, A. E. 2004: Measuring biological diversity. Blackwell Publishing, 256 pp.

McCune, B. \& Mefford, M. J. 1999: PC-ORD. Multivariate analysis of ecological data. Version4. MjM Sofware Design, Gleneden Beach, Oregon, 237 pp.

Oberdorfer, E. 1952: Beitrag zur Kenntnis der nordagaischen Küstenvegetation. Vegetatio 3: 320-349.

Özhatay, N., Byfield, A. \& Atay, S. 2003: Türkiye'nin Önemli Bitki Alanlari, Doğal Hayati Koruma Vakfi (WWF Türkiye) yayini, 88 pp.

Pignatti, S. 2005: Valori di bioindicazione delle piante vascolari della flora d'Italia (Bioindicator values of vascular plants of the Flora of Italy). Braun-Blanquetia 39: 1-96.

Raunkiaer, C. 1934: The life forms of plants and statistical plant geography. Oxford University Press, Oxford, 632 pp.

Seçmen, Ö. \& Leblebici, E. 1997: Türkiye sulak alan bitkileri ve bitki örtüsü. Ege Üniversitesi Fen Fakültesi Yayinlari, İzmir, 158.

Sykora, K. V., Babalonas, D. \& Papastergiadou, E. D. 2003: Strandline and sand dune vegetation of coast of Greece and some other Aegean countries. Phytocoenologia 33(2-3): 409-446.

ter Braak, C. J. F. \& Šmilauer, P. 2002. CANOCO Reference Manual and Cano Draw for Windows User's Guide, Software for Canonical Community Ordination (version 4.5), Wageningen, 496 pp.
Terzioğlu, S. 1998: Uzungöl (Trabzon-Çaykara) ve çevresinin flora ve vejetasyonu, $\mathrm{PhD}$ Thesis, KTU. Fen Bilimleri Enstitüsü, 304 pp.

Thornthwaite, C.W. 1948: An approach toward a rational classification of climate. Geographical Review 38: 55-94.

Tichý, L. 2002: JUICE, software for vegetation classification Journal of Vegetation Science 13: 45-453.

Tutin, T.G., Heywood, V.H., Burges, N.A., Moore, D.M., Valentine, D.H., Walters, S.M. \&Webb, S.A. (eds.) 1964-1980: Flora Europaea, Vol. 15, Cambridge.

Tzonev, R., Dimitrov, M. \& Roussakova, V. 2005. Dune vegetation of the Bulgarian Black Sea Coast. Hacquetia 4(1): 7-32.

Uslu, T. 1974: Mersin ile Silifke arasi kumul ve maki vejetasyonunun bitki ekolojisi ve sosyolojisi yönünden araştirilmasi. PhD thesis, Ankara Üniversitesi Fen Fakültesi, 132 pp. Ankara.

Uslu, T. 1977: A plant ecological and sociological research on the dune and maquis vegetation between Mersin and Silifke - Commun. Fac. Sci. Univ. Ank. 21 C2, suppl. 1 : 60 pp.

Uslu, T. \& Géhu, J.-M. 1990: Syntaxonomic units and flora of Turkish coastal dunes. Proceedings of the 2 nd Int. Colloquy on the Mediterranean Coasts and the Protection of the Environment, Council of Europe, Strasbourg 42 pp.

Westhoff, V. \& van der Maarel, E. 1973: The BraunBlanquet approach. In: R.H. Whittaker (ed.), Handbook of Vegetation Science 5, Ordination and classification of communities. W. Junk, Hague, p. 617-726.

Yaltirik, F. \& Efe, A. 1986: Otsu bitkiler sistematiği, İÜ Fen Bilimleri Enstitüsü Yayini, No. 3568/3, $512 \mathrm{pp}$. 


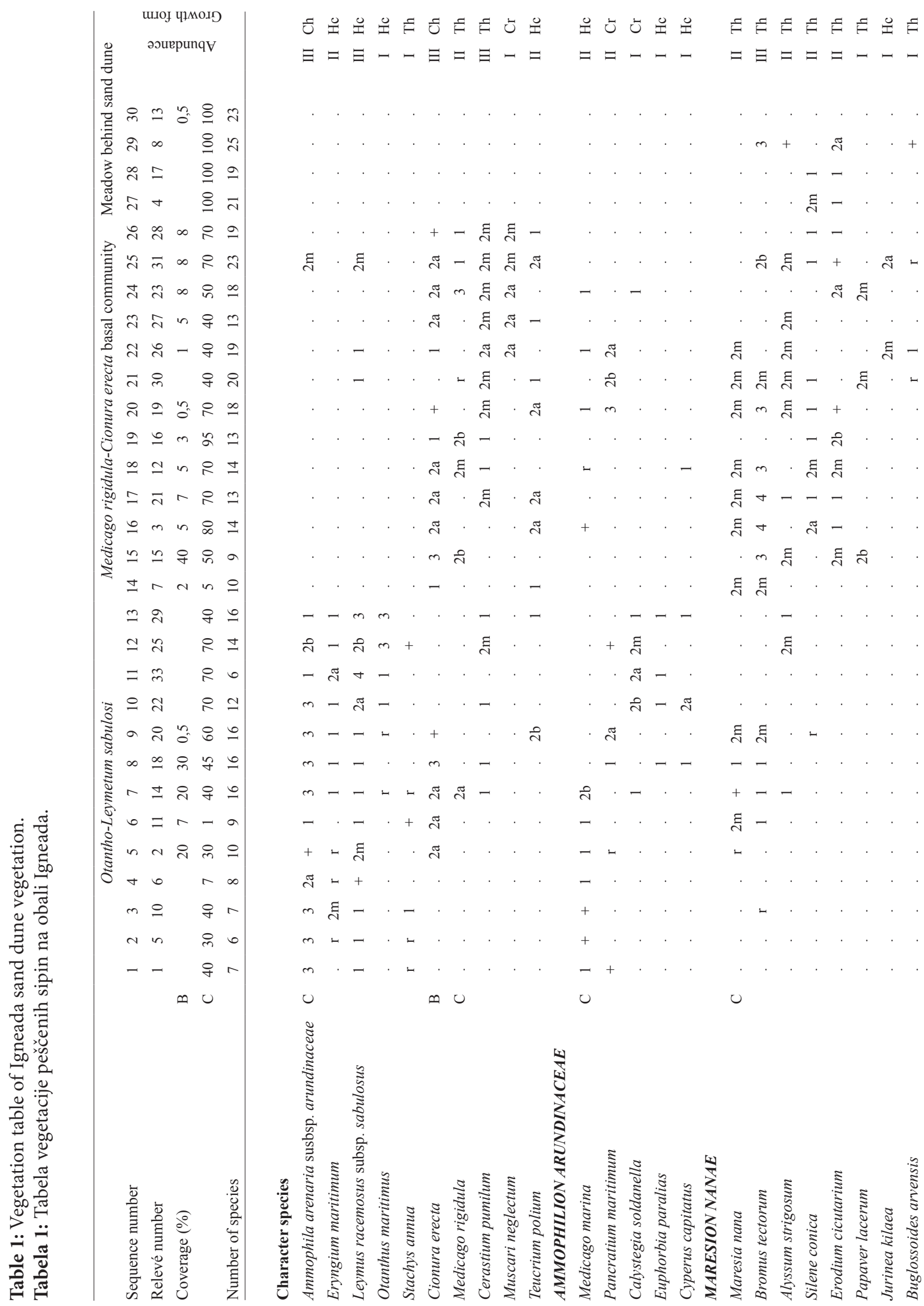




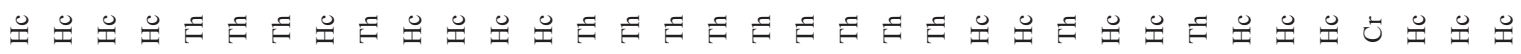

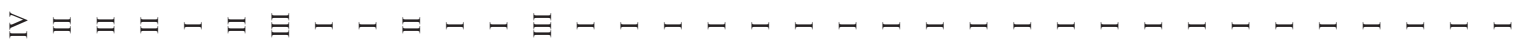
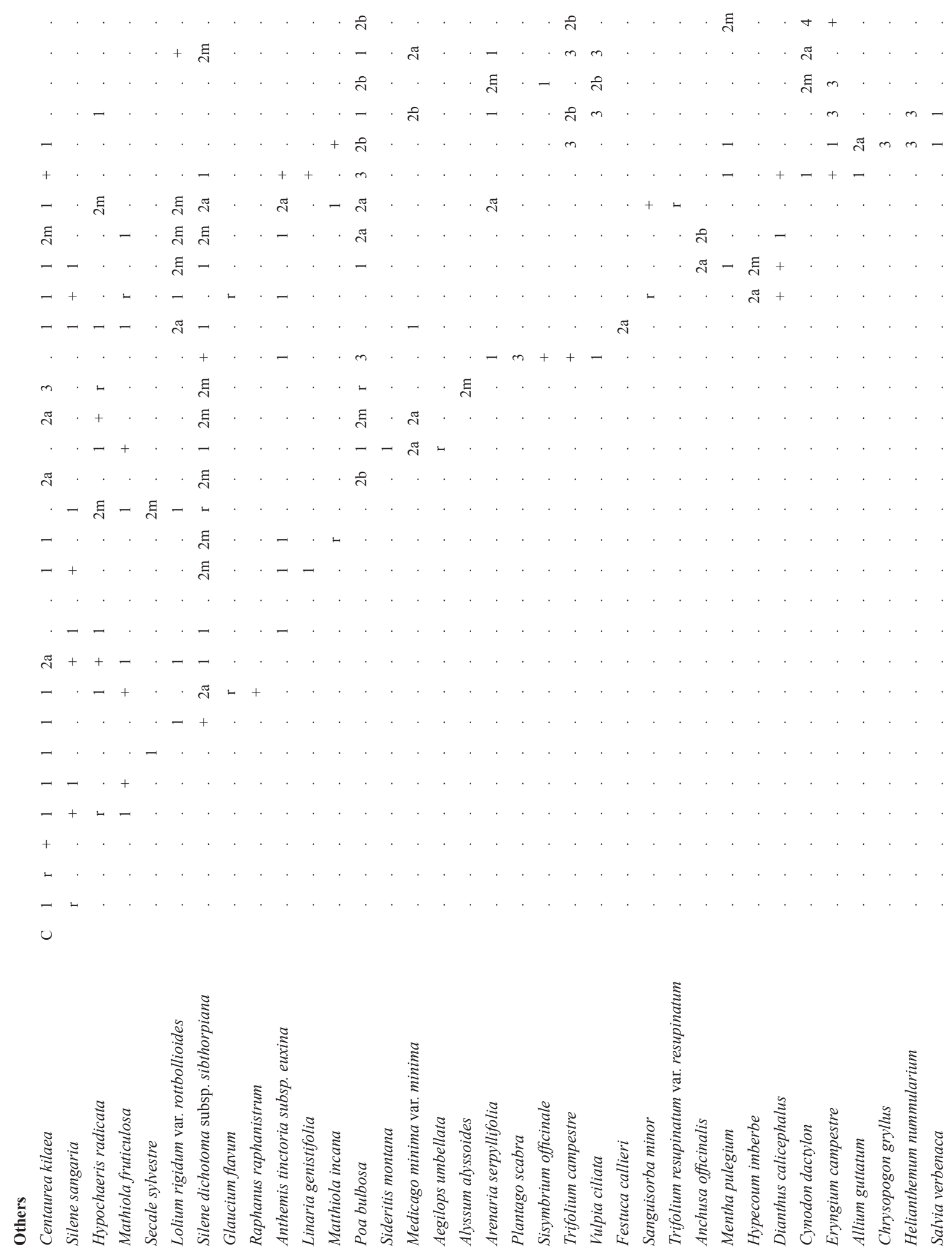

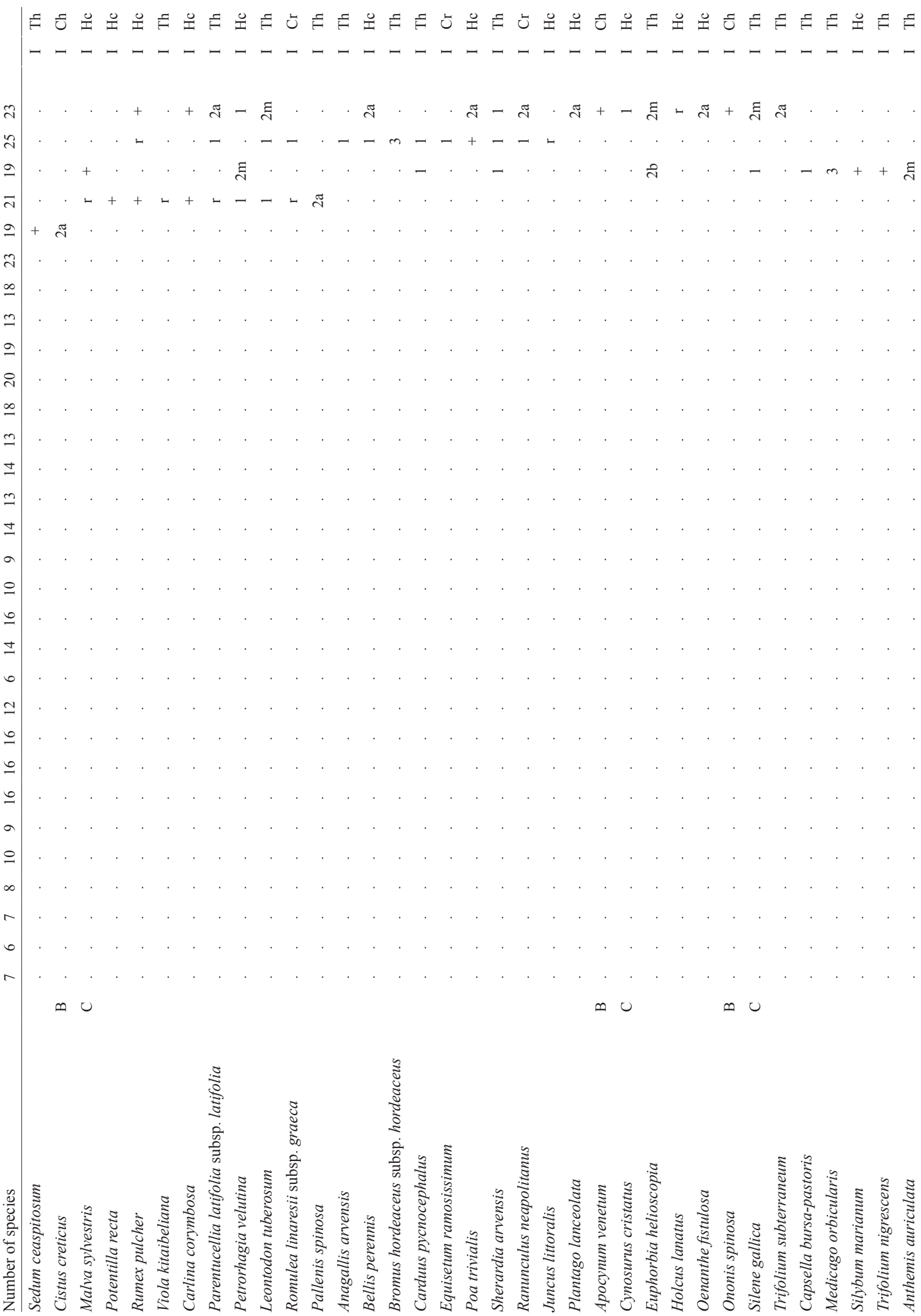